part of Dr. Schmidt's and Capt. Tupman's observations, and has included them with his own former collection, thus forming a very extended catalogue founded on all the similar work of his contemporaries and predecessors, and omitting but few genuine meteoric showers, chiefly in the southern hemisphere, which have only been observed by Dr. Neumayer in Australia.

Following the method of Dr. Weiss, viz, to calculate the radiant points of those comets of early and recent times whose orbits are believed to pass near the earth, a list of such comets for both the northern and southern hemispheres is annexed to Mr. Greg's catalogne, and the cases where they corroborate each other are pointed out. Many important and well-known comets are found to have meteor-showers as their present representatives; as would, perhaps, be still more apparent if more reliable orbits of comets could be used; but the coincidences are, however, numerous enough and sufficiently exact to render desirable the further cultivation of cometary astronomy by the help of starshower observations.

Report on Isomeric Cresols, by Dr. Armstrong.-Little has been done by the committee during the past year. Para and ortho cresols have been obtained from ordinary cresylic acid, but it has not been with certainty determined whether the meta cresol is likewise present, or whether these are the sole constituents of this substance.

Repont of the Committee for the Utilisation of Sicuage, by Prof. Corfield.-The committee has been unable, from want of funds, to carry on the quantitative experiments as they would have wished. Of the total nitrogen supplied to the farms during the year March 25, 1873, to March 24, 1874, 37.7 per cent. was recovered in the crops, during the preceding year $4 \mathrm{r} \cdot 7$ per cent. was recovered, while during the first year of the experiments the nitrogen recovered amounted to 26 per cent. The committee will be enabled, through the liberality of a gentleman, to carry on their investigations during another year.

\section{SECTIONAL PROCEEDINGS}

\section{SECTION A-MiaTHEMATICS}

On the Construction of a perfectly Achromatic Teliscope, by Prof. G. G. Stokes.

At the meeting of the A:sociation in Edinburgh, in $187 \mathrm{r}$, it was stated that it was in contemplation actually to construct a telescope by means of discs of glass prepared by the late Mr. Vernon Harcourt, which should be achromatic as to secondary as well as to primary dispersion. This intention was subsequently carried out; and the telescope, which was constructed by Mr. Howard Grubb, was now exhibited to the Section. The original intenlion was to construct the objective of a phosphatic glass containing a suitable percentage of titanic acid, achromatised by a glass of terborate of lead. The percentage of titanic acid was so chosen that there should be no irrationality of dispersion between the titanic glass and the terborate. As the curvature of the convex lens would be rather severe if the whole convex power were thrown into a single lens, it was intended to use two lenses of this glass, one in front and one behind, with the concave terborate of lead placed between them. It was found that provided not more than about one-third of the convex power were thrown behind, the adjacent surfaces might be made to fit, consistently with the condition of destroying the spherical as well as the chromatic aberration. This would render it possible to cement the glasses, and thereby protect the terborate, which was rather liable to tarnish. At the time of $\mathrm{Mr}$. Harcourt's death two discs of the titanic glass had-been prepared, which it was hoped would be good enough for employment, as also two discs of terborate. These were placed in Mr. Grubb's hands. On polishing, one of the titanic discs was found to be too badly striated to be employed ; the other was pretty fair. As it would have required a rather severe curvature of the first surface and an unusual convexity of the last to throw the whole convex power into the first lens, using a mere shell of crown glass behind to protect the terborate, Prof. Stokes thought it more prudent to throw about one-sixth of the whole convex power into the third or crown-glass lens, though at the sacrifice of an absolute destruction of secondary dispersion, which by this change from the original design might be expected to be just barely perceptible. Of the terborate discs, the least striated happened to be slightly muddy from some accident in the preparation; but as this signified less than the strix, Mr. Grubb deemed it better to employ this disc. The telescope exhibited to the meeting was of about
$2 \frac{1}{2}$ in. aperture, and 28 in. focal length, and was provided with an objective of the ordinary kind, by which the other could be replaced, for contrasting the performance. When the telescope was turned on to a chimney seen against the sky and half the object-glass covered, in the case of the ordinary objective, vivid green and purple were seen about the two edges, whereas with the Harcourt objective there was barely any perceptible colour. It was not, of course, to be expected that the performance of the telescope should be good, on account of the difficulty of preparing glass free from stria, but it proved to be quite sufficient to show the possibility of destroying the secondary colour, which was the object of the construction.

On Cyclone and Rainfall Periodicity in connection with the Sunspot Periodicity, by Charles Meldrum.

The catalogue of cyclones experienced in the Indian Ocean, from 1847 to 1873 , submitted last year, indicated that during this period the number of cyclones in the space between the equator and $34^{\circ} \mathrm{S}$. lat. and the meridians of $40^{\circ} \mathrm{E}$. and $110^{\circ} \mathrm{E}$. are much greater in the years of maximum than in the years of minimum sunspot frequency.

It will now, and in subsequent reports, be shown that not only the number of cyclones, but their duration, extent, and energy, were also much greater in the former than in the latter years, and that there is a strong probability that this cyclonic fluctuation has been coincident with a similar fluctuation of the rainfall over the globe generally.

The present communication is confined to the twelve years I $856-67$, comprising a complete sunspot cycle.

With regard to the cyclones of the Indian Ocean, the investigation is based upon the extensive collection of observations made by the Meteorological Society of Mauritius on the assumption that the observations are so numerous that no cyclone of any considerable extent or violence can liave escaped detection.

A chart has been prepared for noon on each day of the period during which a cyclone lasted. The chart shows the positions of the vessels, the directions and force of the wind, the state of the weather and sea, \&c. In this way the position of the centre of the cyclone is ascertained for each day ; then, by examining the several charts, the duration, extent, \&c, of the cyclone are determined.

The number of cyclones thus examined for the twelve years is II 3 , and their tracks have been laid down on six charts.

The total cyclonic area in 1860 and 1861 was about twelve times greater than in 1856 and $185 \%$, and nearly eight timcs greater than in 1867 ; in short, all the factors were greater in the years of maximum sumspot frequency. It is evident from the table that the cyclonic area increased rapidly from 1858 to 1860 , and diminished slowly from $186 \mathrm{I}$ to $\mathrm{I} 866$. The registers for the years 1856, 1857, 1866, and 1867 have been examined with special care in order that nothing might be omitted; and, to give the utmost possible weight to those years, every instance of even an ordinary gale has been taken into account. In 1856 there was no great hurricane at all, and the same may be said of 1857 , 1866, and I867. From the chart for I806 it will be seen thut in April of that year there was a number of small cyclones. The south-east trade-winds and north-west monsoon were in collision for a considerable time, and several cyclonic eddies of short duration were formed.

If we could obtain good values of the mass of air in motion and the velocity of the wind, it would probably be found that the ratios of cyclonic energy were greater than those of cyclonic area, for in the maxima years the cyclones were much more violent than in the minima years. Assuming the mass to be nearly proportional to the area, and the velocity of the wind in a strong gale to be 55 miles, in a whole gale 70 miles, and in a hurricane 85 miles an hour, the amount of cyclonic energy in r860 was about eighteen times greater than in 1856 , the squares of the velocities being as three to five.

Although the results are necessarily rough approximations, yet the fact that the number and violence of the cyclones of years of maximum sunspot were far greater than in the years of minimum sunspot is beyond all doubt.

When a great hurricane takes place in the Indian Ocean, the disabled ships are obliged to put into the nearest port, and the newspapers in their shipping intelligence announce the arrival of the vessels, the dates and localities of the bad weather, and the amount of damage sustained. For upwards of twenty years the Commercial Gazette of Port Louis has published all arrivals of vessels and all maritime events which have been reported by them. Considering, then, the geographical position of Mauritius, 
a cyclone periodicity, if one exists, should be traceable in the shipping intelligence. Now, from Table II., which gives the published reports for 1856 , 1860, and 1867 , it will be seen that the number of storms and the damage sustained in 1856 and r 867 were insignificant compared with the long list of hurricanes and disasters in 1860 .

Table III. gives as complete a list of hurricanes and storms experienced in Mauritius as I have hitherto been enabled to prepare. The list comprises only such storms as from the violence of the wind committed considerable damage.

Table IV., which contains a list of Bourbon (Réunion) hurricanes and gales from $r 733$ to 1754 , shows also the number of hurricanes that occurred in the maximum and minimum sunspot years.

For the two islands the number of cyclones in the maxima years was thirty-six, and for the minima years nineteen. This result is favourable.

It wonld appear also from M. Poey's researches, and from investigations made at Mauritius in 1872 , that the cyclones of the West Indies are upon the whole subject to the same periodicity. The rainfall for the twelve years under discussion is given in Tables V. to IX. It thence appears from the xainfall at sixtyseven stations that the maximum fall was in the years 1859 to 1862 , and the minimum in the years 1857,1858 , and 1864 . We thus find a certain degree of correspondence between the cyclone and rainfall fluctuations; and it is possible that if we had returns from America the correspondencé would be much greater; for it would appear from researches by Mr. G. M. Dawson, that the Jevel of the American great lakes was considerably less in 1867 68 than in $\mathbf{1} 859-6 \mathrm{I}$. (The year 1867 has been almost the only exception to the rule in Europe since the commencement of the century, and as most of the stations are in that part of the world tle results for 1856 and 1857 are not so favourable as for previous cycles).

A large number of additional rainfall returns has been received from Europe and other parts of the world, and the results, which will be communicated in another report, afford fresh evidence of a rainfall periodicity.

(The paper was accompanied by several elaborate tables).

\section{SECTION B-Chemical ScIEnce}

On some Opizun Derizatives, by Dr. C. R. A. Wright.-The action of free chlorine on codeine is to produce higher polymericles, especially tricodeine, from which again, by the action of hydrochloric acid, apocodeine is formed. This apocodeine may be looked on as three molecules of codeine mininus six molecules of water. Narceine is feebly basic, but it has a strong attraction for hydrochloric acid, giving rise to the crystailisable hydrochloride $\mathrm{C}_{23} \mathrm{H}_{29} \mathrm{NO}_{9}+\mathrm{HICl}$. If the salt is dissulved in boiling water, Ciystals are obtained containing six molecules of $\mathrm{C}_{23} \mathrm{H}_{299} \mathrm{NO}_{4}$ plus one molecule of $\mathrm{HCl}$. basic chlorides, probably not definite compounds, have also been oblained. With excess of hydrochloric acid at $100^{\circ}$ the elements of water are removed from narceine, and we get $\mathrm{C}_{23} \mathrm{H}_{87} \mathrm{NO}_{8}$. The bydrochloride of this base is non-crystallisabie. By the action of glacial acetic acid on codeine there is produced diacetyl codeine, $\mathrm{C}_{36} \mathrm{H}_{40} 2\left(\mathrm{C}_{2} \mathrm{H}_{3} \mathrm{O}\right)$ $\mathrm{N}, \mathrm{O}$. Acetic acid acts in a similar way on morphine, a considerable quantity of triacetyl morphine being also produced. Acetic anhydride gives rise to the formation of an isomeric diacetyl morphine. We have, therefore,and $\stackrel{\alpha}{\beta}$

$$
\text { a diacetyl morphine . . . crystallisable }
$$

and " " " nour-crystallisable. acetic acid and strychnine. The following yeneral formulæ for the morphine and codeine salts are given :-

$$
\begin{aligned}
& \mathrm{M}+n \mathrm{HX}-n \mathrm{H}_{2} \mathrm{O}, \\
& \mathrm{C}+n \mathrm{HX}-n \mathrm{H}_{2} \mathrm{O},
\end{aligned}
$$

when IIX = a monobasic acid.

On a Phenomenon noticed on "boring a Well, by Dr. Andrews. - The author described a remarkable jet of almost pure marsh vas, obtained on boring a well near Belfast. The borings first descended through about $33 \mathrm{ft}$. of silt, and then reached a gravelly deposit $7 \mathrm{ft}$. in thickness, interspersed with organic débris. It was from this deposit that the marsh-gas was evolved.

Reaction of Hydrogen, Peroxide, Soc., by Mr. Fairley.-The author believes that he has succeeded in preparing hypochlorous acid according to the equation $\mathrm{H}_{2} \mathrm{O}_{2}+\mathrm{Cl}_{2}=2 \mathrm{HClO}$. By the action of hydrogen peroxide on bleaching powder, and on other hypochlorites, oxygen is evolved; thus, with potassium hypo chlorite, $\mathrm{KClO}+\mathrm{H}_{2} \mathrm{O}_{2}=\mathrm{KCl}+\mathrm{H}_{2} \mathrm{O}+\mathrm{O}_{2}$. Chloric acid has no action on hydrogen peroxide; neither has sulphuretted hydrogen in the absence of air. By the action of ozone on hypo. chlorous acid there seems to be produced perchloric acid.

On the General Equations of Chemical Decompositzon, by Prof. Clifford, F.R.S.-This paper was also read before Section A. The author thirks that chemical equations may be brought under a general formula. Thus, $\mathrm{H}_{2}+\mathrm{Cl}_{2}=2 \mathrm{HCl}$. If we assume that there is a structure common to the hydrogen and the chlorine atoms, also a structure confined to the hydrogen and likewise a structure confined to the chlorine atoms, we may represent this equation thus: $X Y Y+X Z Z=2 X Y Z$, when $X$ represents the common structure and $\mathrm{Y}$ and $\mathrm{Z}$ the structures which are confined to hydrogen and chlorine respectively. So $2 \mathrm{H}_{2}+\mathrm{O}_{2}=2 \mathrm{H}_{2} \mathrm{O}$ may be represented thus : $2 X Y+X X Z Z=2 X X Y Z$. These equations involve no hypotheses, because the fundamental facts of the molecular theory are now firmly established. Reasoning from these and similar equations, the author deduces the result that the ordinary equations of chemistry, such as those just stated, are expressive of facts, and that the hydrogen molecule really consists of two equal atoms.

On the presence of Cycanogen in Commercial Bromine, and a means of detecting it, by Dr. '1. L. Phipson.-The author states that commercial bromine often contains cyanogen ; by adding an equal weight of iron filings and four to five times its weight of water to the bromine, stirring, filtering, and allowing the filtrate to remain for twenty-four hours in a closed bottle, a precipitate of Prussian blue is thrown down if cyanogen is present.

On a Sesqui-sulphide of Iron, by Dr. Phipson.-The author describes a greenish black salt having the composition $\mathrm{Fe}_{2} \mathrm{~S}_{3}$. This salt is produced by precipitating a ferric salt by means of ammonium sulphide in the presence of a free chlorite or hypochlorite. The salt is soluble in hot water, also in ammonia, giving an emerale green liquid.

On the Chlor-bromides and Brom-Jodides of the Ulcfines, by Prof, Maxwell Simpson, F.R.S.-The author described various substances obtained by acting on ethylene, \&c., with iodine chloride, with bromine chloride, with bromine iodide, \&c. In the case of ethylene the substance $\mathrm{C}_{2} \mathrm{H}_{4} \mathrm{BrI}, \mathrm{C}_{2} \mathrm{H}_{4} \mathrm{ClI}$, and $\mathrm{C}_{2} \mathrm{H}_{4} \mathrm{ClBr}$, were described. These bodies may also be obtained by agitating the chloride bromide or iodide of ethylene with a solution of iodine or bromine chloride : thus, $\mathrm{C}_{2} \mathrm{H}_{4} \mathrm{Br}_{2}+\mathrm{BrI}=$ $\mathrm{C}_{2} \mathrm{H}_{4} \mathrm{BrI}+\mathrm{Br}_{3}$. The reaction $\mathrm{C}_{2} \mathrm{H}_{4} \mathrm{Cy}_{2}+\mathrm{BrCy}=\mathrm{C}_{2} \mathrm{H}_{4} \mathrm{CyBr}+$ $\mathrm{Cy}_{2}$ would not take place ; indeed, the author was totally unable to prepare the brom- or iodide cyanide corresponding to the salts just mentioned.

On an Aspirator, by Dr. Andrews, F.R.S., and On another forth of Aspirator, by Prof. Delffs, could not well be understood without drawings.

\section{SECTION C-GEOLOGX}

The Geologicul Structure of the Tyrone Coal-field.-Mr. Hardman, after describing the position of these beds, remarked that the carboniferous rocks of this district appear to resemble somewhat those of the northem counties of England. The coalhearing beds are true coal measures. The underlying limestone is split up by numerous sedimentary beds, and, on the wh ole, agrees with the Ballycastle coal-field, which beds Prof. Hull assigns to the same horizon with tho.e of the Scotch cual measures. The author referred in detail to the thickness and josition of the beds. With reference to the Dungannon coaltield, which extends from near Dungannon to beyond Coalisland, he remarked that though small in area it was rich in coal seams, possessing twenty-four coal-beds, of which at least thirteen were workable. They are highly bituminous, and two of the beds contain valuable seams of cannel coal. The chemical analyses show that these coals are valuable, possessing from $37^{\circ} 5$ to 47 per cent. of volatile matter for gas manufacture. In the upper measures we have valuable deposits of fire-clay, which are extensively used for the manufacture of bricks and tiles. The irunstones are not sufficiently abundant to be worked, yet they yield as much as $2 \mathrm{I}^{\prime} \mathrm{\gamma}$ to $35^{\circ} \mathrm{5}$ per cent. of metallic iron. There must be from $30,000,000$ to $40,000,000$ tons of coal yet untouched. If we count the smaller beds we shall have at least $9,000,000$ more. The coal-field is bounded on the north-west by a large fault, which brings down the coal measures on the south against the calp and lower fimestone. It must have a downward throw of 2,000 feet. Northwards, the limestone is covered by trias, 
without any intervening coal measures, for three-and-a-half miles, when a small trough of the middle coal measures, with four of the upper Coalisland beds, rise up. This field is but twon and-a-half miles long, and a quarter wide, and yet it must contain the whole series of the middle and lower coal measures, the millstone grit and Yoredale beds. Here, the author calculates, there are 800,000 tons of coal. The author proceeded to explain when and how the two coal-fields became isolated from each other; and why, in the immédiate vicinity of these coal measures, the Permian rocks are found reposing directly on the limestone. At the close of the carboniferous period the rocks were forced into flexures, ranging east and west, owing to forces acting from the northwards, as Prof. Hull shows acted in England. Denudation following, we had a set of plains, or edges of limestone, and troughs of coal measures, all of which were overlapped by the Permian and Trias. On subsequent denudation and post-triassic faults occurring, some portions of the coal measures would be laid bare or saved beneath the newer formations. As the whole district is cut up by faults, and the rock exposures few, the evidences of these flexures are obscure.

\section{SECTION D-BIOLOGY}

Defartment of Zoology and Botany

Dr. Williams read a paper On Specimens of Alga from Fersey. The paper referred to the large number of species of marine algat to be found at Jersey, and to the favourable position of the island for their development. Dr. Williams produced a splendid collection of alge preserved by a lady residing in Dublin.

Prof, Lawson read a paper On cortain peculiarities in the Indicun Anpelidec. He remarked that many of the species were climbers, with their branches interlacing in the tops of the highest trees. In the stems of all were to be found numerous very large ducts, and these ducts were filled with intra-cellular vesicles, in which, at a certain time of year, abundance of starch was developed. He also remarked that in the fruit most important differences might be found, but that these afforded no means by which to divide the genus into natural sections. With respect to the inflorescence, he saic there was great variety of form. Two species only reached the eastern coast of Africa, most being confined to India, though some few were common throughout the Malayan Archipelago.

On the Grozeth of Tree-ferns, by D. Moore.-The general conclusions arrived at in this paper were (I) Some of the kinds of tree-ferns grow with greater rapidity and form their stems in a much shorter period than is generally supposed to be the case; (2) After they attain a certain height the acrogenous buds are formed much closer together, one above the other, than they are lower down on the stem; hence their elongation is much slower; (3) Some of the sorts which at first form short rhizomatous stems before they take an upright position require a considerable number of years to perfect the early parts, but after the stem has been formed and an upright position taken, the growth is much quicker and the elongation advances rather rapidly compared with it, while the stem remains in a rhizomatous state.

Mosses of the North of Ireland, by S. A. Stewart.-Turner, in 1804 , enumerated as Irish 230 species of mosses; Dr. Taylor, in 1836 , mentions about the same number; and Dr. D. Moore, in 1872 , gives a list of 385 Irish species, to which the author of the present paper adds four others, viz., 389 , or more than twothirds of the British mosses. Thus, relatively to the British Flora, Ireland has quite as large a proportion of mosses as she has of flowering plants, proving that Irish muscology has not been neglected. No separate lists of the mosses occurring in the northern counties have been published; but after consulting the records of Dr. Taylor in the "Flora Hibernica," and the valuable list of Irish mosses by Dr. Moore, also some detached papers on the subject, the author ascertains that the number of species occurring in the district amounts to 195, or more than one-half of the Irish mosses. The district is defined to consist of the counties of Down and Antrim, with a small portion of Co. Dexry, bordering on Antrim. The list includes a large number of rare mosses. The following have not been previously recorded as Irish, viz.:- Fissidens incurvis $\mathrm{Schw}$. var. Lylei, found only on a greensand rock on the Black Mountain, near Belfast; Tayloria serrata, in small quaritity, near the summit of Benbradagh Mountain, Co. Derry ; Minum sublobosum, in wet peat bog on Care Hill, near Belfast, and in a similar habtat on
Carrickfergus Common; Seligeria calcarea, on Black Mountain, near Belfast, appearing like black specks on small lumps of chalk in the grass. Mr. C. P. Hobkirk, of Huddersfield, has been Ikind enough to identify the specimens of the above-named mosses.

Prof. Dickson exhibited specimens of an abnormal form of the ox-eye daisy (Chrysanthemum liucanthemunh), in which the outer florets of the ray (normally ligulate and female) exhibit an irregularly tubular corolla, not very unlike that in the nenter florets in certain Centaureas. Structurally these abnormal florets are hermaphrodite, but appear always to be functionally neuter or sterile.

Mr. Bentham remarked that similarly abnormal tubular florets, structurally hermaphrodite, and functionally neuter, occur in certain varieties of Chrysanthemun indicum and Dahlia.

Mr. G. Bentham, F.R.S. read a report On the recent progress and present state of Systematic Botany, commencing with a sum. mary sketch of the state of science in 1830 , when the natural method of Jussieu was beginning to supersede the sexual system of Limmeus; ; of its progress from that year to 1859 , when the study of the general affinities of plants had entirely superseded the classing them according to single organs; and of the great advance effected since 1859 , owing to the explanation of affinities given by the adoption of the doctrine of evolution. After some notes on the language to be preferred, systematic works were then considered under the six several heads of Ordines plantarumi, Genera plantartm, Spccies plantarzm, Monographs, Floras, and niscellaneous descriptions. Under each head the particulars required were specified, the principal recent works glanced over, with a short mention of the chief desiderata now recommended to the attention of systematic botanists.

Prof. Thiselton Dyer referred to the paper as evidencing the labour necessary to acquire a proficiency in the knowledge of botany. Some people thought botanical study was a kind of pastime, but the paper just read proved the contrary.

Sir John Lubbock believed that mutatis mutandis a great deal of what Mr. Bentham said with regard to systematic botany would apply equally to zoology.

Prof. Dickson gave the results of his investigations on the embryogeny of Tropaolum pereorinum and Tropacolum speciosum. In these species the principal peculiarity consists in the constant penetration of the carpellary tissue by the extra-seminal root. process. In Tropizolium mnjiss the extra-seminal root-process developed from the outer side of the base of the suspensor. After perforating the seed-coat it becomes elongated, and finishes its course in the cavity of the seed-vessel. In rare cases, however, this process has been found to penetrate by its very extremity the carpellary tissue. In Tropaolum peregrimum the extraseminal process penetrates the carpel after having run in the cavity of the seed-vessel half-way. In Tropcoolum speciosum this process dips into the carpel immediately after emerging from the seed. Dr. Dickson remarked that some would be disposed to look upon the abnomality in Tropicolimn snajus and the normal form in Tropacolum peregrinum as forms representing what might be viewed as stages in the evolution of such a species as Tropicolum speciosumin from some form analogous to Tropacolatin majus. In regard to this, Dr. Dickson adversely criticised the Darwinian hypothesis, as, in his opinion, inapplicable to the case under consideration.

Mr. A. W. Bennett read a paper On the form of poilen-grains in reference to the fortilisation of flowers. He stated that although not unfrequently a common form of pollen-grain runs through a whole group of plants, yet more often the form is found to be adapted to the requirements of the species, and varies even within a small circle of affinity. In those plants which are fertilised by the agency of insects, there are three general modes in which the form of the grain is adapted for the purpose. We have, firstly - and this is by far the most common form-an elliptical grain, with three or more longitudinal furrows, as in Ranunculus ficaria, Aucuba japonica, and Bryonia dioica; secondly, spherical or elliptical, and covered with spines, as in many Composita, Malvacere, and Cucurbitacex; and, thirdly, where they are attached together by threads or a viscid excretion, as in Richardia FEthiopica. In those plants, on the contrary, which are fertilised by the agency of the wind, as most grasses, the hazel, and Populus balsamifera, the pollen is almost perfectly spherical. and unfurnished with any furrows, and is generally, moreover, very light and dry. The grenus Viola supplies two very markedly different firms, in one of wh i.h, the section to which $t$. conthis and 7 , orenta lelong, the grains have the crinary clipticit 
three-furrowed form, and where every point of the structure of the style and stigma is favourable to fertilisation by bees; the other, the section to which $V$. tricolor belongs, where they are very much larger and either pentagonal or hexagonal, and the style and stigma are adapted for fertilisation by Thrips. In all Crucifers hitherto known the pollen has the most common form. Pringlea antiscorbutica, the "Kerguelen's Land cabbage," has been shown by Dr. Hooker to be wind-fertilised, from the following considerations: the absence of petals, the absence of honey-glands, the exserted style, and the stigma being covered with long papillze. The form of the pollen supports the same view, being very small and perfectly spherical, extremely different therefore from every other plant of the order. In the cowslip and primrose there is a uniform difference in size between the pollen belonging to the two dimorphic forms, that of the short-styled being always considerably larger than that of the long-styled form. An interesting discussion followed, in which Dr. Hooker, Prof. Dickson, Sir J. Lubbock, Prof. Balfour, and Mr. W. E. Hart took part.

\section{SCIENTIFIC SERIALS}

Menorie della Suciela deyli Spottroscopisti Italiani, June.This number contains a very interesting account of the theories of the cause of formation of comets' tails, by Schiaparelli. The author seems to have no doubt that a repulsive force is in action, and that the only two acceptable theories are that the force is due to electricity or the repulsive power of the sun's heat.Tacchini contributes a note on the polarisation of the zodiacal light, in which he corroborates Wright's observations of polarisation, and the presence of reflected sunlight. He also adds position observations of Coggia's comet in June.-Prof. Lorenzoni contributes a paper On some theoretical researches for a manner of rendering the whole of the solar chromosphere visible at once.

Bulletin de l'Acadénie Royale de Belgrigue, tome 37, No. 6.This number contains an article by M. P. I. Van Beneden, On the whales of New Zealand. He refers to the fact that Dr. Gray of the British Museum has recognised three species in the New Zealand district, Neobalena marginata, Caperea antipodium, and Macleayins australiensis, and urges that among the right whales there should be but one genus, b'alona. Those genera were established on imperfect data, and now that we have more material, several supposed diaynostics are found not to exist, and those that are established are of no great importance. As regards the skeleton at the Museum at Paris, studied by Prof. Liiljeborg, being without the ear-bone, that had been removed to be figured, and had not at the time been replaced. It is reported, however, as safe. Dr. Gray, believing that Van Beneden's drawing of the ear-bone was from some other source, erected it into a new genus. --MM. Cornet and Briart draw attention to some little known beds of phosphate of lime in the cretaceous beds of Hainault, and urge their being worked commercially.-M. Gluge gives a short note on tonic muscular contraction being converted into rhythmic contraction. His observations were on the sphincter ani muscles of rabbits, and he refers to similar experiments by M. Goliz on a dog. He believes that such experiments may lead to the explanation of the rhythmic contraction of the heart.

\section{SOCIETIES AND ACADEMIES PARIS}

Academy of Sciences, Sept. 14.-M. Bertrand in the chair.-The following papers were read:-Science before gcammar, by M. E. Chevreul. A considerable portion of the paper (which is but an abstract of a more lengthy memoir) is devoted to a discussion of the word "fact." The author also d.aws a parallel between psychic and chemical analysis, the former separating simple ideas perceptible by the mind, and the latter ponderable simple substances perceptible by the senses. The difference between the moral and political sciences and the sciences of the domain of natural philosophy is pointed out, and in an appendix the author states his reasons for dissenting from scepticism and moterialism.-On a particular toxic action exercised at a distance by Colchicum autnmmale at the time of flower. ing ; extract from a letter from M. Is. Pierre to M. Dumas. The hand, when held near the anthers of the flowers without coming into actual contact with them, changes in a few seconds to a livid greenish-yellow colour. The natural colour returns about ten se. conds after the removal of the hand. The author believes that this remarkable action is chiefly exerted during or near the period of fertilisation, and proposes to examine further the nature of the substance emitted.-New conditions for the production of the silent electrical discharge ; its influence on chemical reactions ; by M. A. Boillot. The author concludes, from his experiments, that the space traversed by the silent discharge can be considerably augmented without a diminution in the chemical effects produced.-On some tungsten minerals from Meymac (Correze), fourth note, by M. Ad. Carnot. The minerals now described are wolfram (containing $\mathrm{FeWO}_{4}$ and $\mathrm{MnWO}_{4}$ ) cal. careous scheelite (containing $\mathrm{CaWO}_{4}$ ), and hydrated tunstic acid, to which the author assigns the formula $2 \mathrm{WO}_{3}, 5 \mathrm{HO}$, or $\mathrm{WO}_{3}, 2 \mathrm{HO}$ (old notation), - On the supposed migration of winged Phylloxera t) Quercus coccifera, by M. Balbiani. The author states his belief that the species seen by M. Lichtenstein on this tree is not identical with Phylloxera vastatrix. The following species of Phylloxera are recognised in addition to vastatrix:-P. quercus, especially inha. biting Quercas pedunculata, and $P$. coccina, inhabiting $Q$. robur. The species found by M. Lichtenstein on Q. coccifira it is proposed to name $P$. lichtensteinit. - Experiments on the employment of alkaline sulpho-carbonates for the destruction of Phylloxera; a letter from M. Mouillefer to M. Dumas. -On new points at. tacked by Phylloxer a in Beaujolais ; a letter from M. Rommier. - On the actual state of the invasion of Phylloxera in the Charente provinces; extract from a letter from M. Maurice Girard. - Employment of the water used in purifying gas for the destruction of P/hylloxera; a leiter from M. G. Beaume. -Note on the action exercised by the soil of vine fields on sulphuretted gises, and memoir On the propagation of Phylloxira, by $M$. Cauvy.-Other communications were received on the same sub. ject from various authors, and $M$. Jumas gave a résumé of $M$. Balbiani's observations, and stated that in future the sending of living specimens of the insect to Paris would be interdicted. The Minister of Foreign Affairs forwarded to the Academy a communication from the French Consul at Messina, relating to the opening of new vents of eruption in Etna, and on some earthquakes felt at Messina.- - On a transformation of the equa. tions of celestial mechanics, by M. Allégret.--On the causes which modify the setting of plaster, new cements with plaster and lime bases, by M. Ed. Landrin.-Action of heat on phenylxylene, by M. P. Barbier. The products are anthracene, benzene, and xylene, produced thus-

$$
{ }_{2} \mathrm{C}_{14} \mathrm{H}_{14}=\mathrm{C}_{14} \mathrm{H}_{10}+\mathrm{C}_{6} \mathrm{H}_{6}+\mathrm{C}_{8} \mathrm{H}_{10}+\mathrm{H}_{2} \text {. }
$$

-On a case of decomposition of chloral hydrate, by $\mathrm{M}$. Tauret. by the slow oxictation of this substance, carbonic oxide is liberated. The author thinks this furnishes a new explanation of the action of chloral upon the system, and accuunts for the accidents occasionally resuiting from its use.-On the development of red vapours during the boiling of saccharine juices in manufacture, by M. E. J. Maumené. The auchor attributes these to the action of nitrates. On the rôle played by gas in the coagula. tion of the blood, by MM. E. Matthieu and V. Urbain.--Syn. thesis of purpurine, by M. F. de Lalande. This was effected by the action of oxidising agents on pure alizarine.-During the meecing, a communication was read from his Majesty the Emperor of Brazil, offering his thanks to the Academy for adding a young brazilian astronomer to one of the Transit of Venus expeditions.

\section{CONTENTS}

The Migration of Binds. By Prof. Alfred Newton, F.R.S. . Pagh Competitive Examinations . . . . . . . . . 415

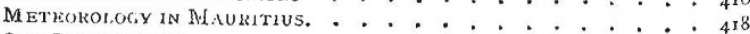
OUR BOOK SHE1F. . . . . . . . . . . . . . . ${ }_{41}^{16}$ LatTRRS TO THE EDITOR :-

Fossils in Trap.-E. A. WuNsCh . . . . . . . . . . 410

Chrysomela Banksii.-H. Power . . . . . . . . . . . . . 4 4

Meteor.-G. H. Hopkins. . . . . . . . . . . . . . . . . . . . $44_{419}^{4}$

The Inteknational Congress of Orientalists . . . . . . . . . 419

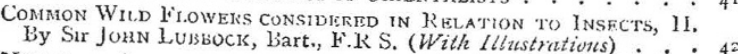
Notes . . . . . . . . . . . . . . . . . . 426

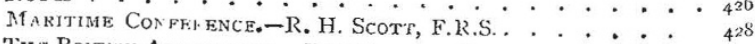

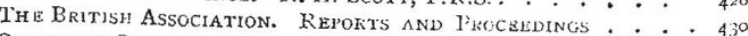
Scientific Setrials. . . . . . . . . . . . . . . . 434 SOCIETIES AND ACAD Emies 